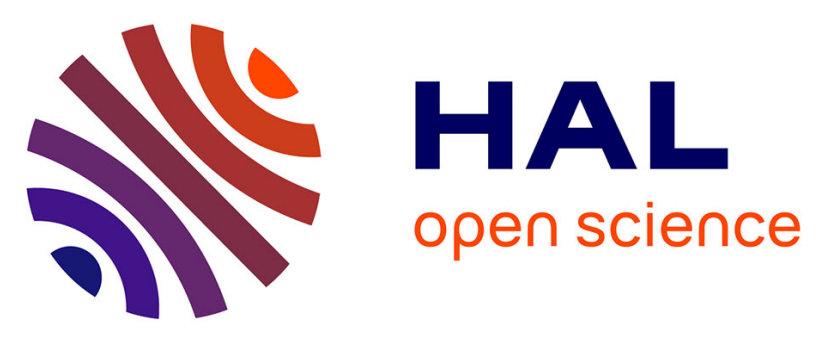

\title{
Performance of plasma sputtered Fuel Cell electrodes with ultra-low Pt loadings
}

\author{
Marjorie Cavarroc, A. Ennadjaoui, Mathieu Mougenot, Pascal Brault, \\ Raphael Escalier, Y. Tessier, Jean Durand, S. Roualdes, T. Sauvage, \\ Christophe Coutanceau
}

\section{To cite this version:}

Marjorie Cavarroc, A. Ennadjaoui, Mathieu Mougenot, Pascal Brault, Raphael Escalier, et al.. Performance of plasma sputtered Fuel Cell electrodes with ultra-low Pt loadings. Electrochemistry Communications, 2009, 11 (4), pp.858-861. 10.1016/j.elecom.2009.02.012 . hal-00361475

\section{HAL Id: hal-00361475 \\ https://hal.science/hal-00361475}

Submitted on 15 Feb 2009

HAL is a multi-disciplinary open access archive for the deposit and dissemination of scientific research documents, whether they are published or not. The documents may come from teaching and research institutions in France or abroad, or from public or private research centers.
L'archive ouverte pluridisciplinaire HAL, est destinée au dépôt et à la diffusion de documents scientifiques de niveau recherche, publiés ou non, émanant des établissements d'enseignement et de recherche français ou étrangers, des laboratoires publics ou privés. 


\title{
Performance of plasma sputtered Fuel Cell electrodes with ultra-low Pt loadings
}

\author{
M. Cavarroc ${ }^{\mathrm{a}}$, A. Ennadjaoui ${ }^{\mathrm{a}, \mathrm{b}}$, M. Mougenot ${ }^{\mathrm{c}, \mathrm{d}}$, P. Brault $^{\mathrm{c}, *}$, R. Escalier ${ }^{\mathrm{c}}$, Y. Tessier $^{\mathrm{c}}, \mathrm{J}$. \\ Durand $^{b}$, S. Roualdès ${ }^{b}$, T. Sauvage ${ }^{e}$, C. Coutanceau ${ }^{f}$ \\ ${ }^{\mathrm{a}}$ MID Dreux Innovation, CAdD, 4 Rue Albert Caquot - 28500 Vernouillet, France \\ bInstitut Européen des Membranes, ENSCM, UM2, CNRS ; Université Montpellier 2, CC047, Place Eugène \\ Bataillon, 34095 Montpellier cedex 5, France \\ ‘Groupe de Recherches sur l’Energétique des Milieux Ionisés, CNRS Université d’Orléans, BP6744, 14 rue \\ d’Issoudun, 45067 Orléans, France \\ ${ }^{\mathrm{d}}$ MHS Equipment, 104 Bd Jean-Jaurès BP101, 78808 Houilles cedex, France \\ e Conditions Extrêmes et Matériaux : Haute Température et Irradiation, UPR3079 CNRS, Site Cyclotron, 3A rue \\ de la Férollerie, 45071 Orléans Cedex 2, France \\ f Laboratoire de Catalyse en Chimie Organique, UMR6503 Université de Poitiers, CNRS, 86022, Poitiers, \\ France.
}

\begin{abstract}
Ultra-low Pt content PEMFC electrodes have been manufactured using magnetron cosputtering of carbon and platinum on a commercial E-Tek ${ }^{\circledR}$ uncatalyzed gas diffusion layer in plasma fuel cell deposition devices. Pt loadings of 0.16 and $0.01 \mathrm{mg} \mathrm{cm}^{-2}$ have been realized. The Pt catalyst is dispersed as small clusters with size less than $2 \mathrm{~nm}$ over a depth of $500 \mathrm{~nm}$. PEMFC test with symmetric electrodes loaded with $10 \mu \mathrm{g} \mathrm{cm}^{-2}$ led to maximum reproducible power densities as high as $0.4 \mathrm{~W} \mathrm{~cm}^{-2}$ and $0.17 \mathrm{~W} \mathrm{~cm}^{-2}$ with Nafion ${ }^{\circledR} 212$ and Nafion ${ }^{\circledR} 115$ membranes, respectively.
\end{abstract}

\section{Keywords}

Platinum; Solid polymer electrolyte; Fuel cell; Plasma sputtering deposition; ultra low platinum loading

\footnotetext{
* Corresponding author: Fax: +33 23841 71 54; email: Pascal.Brault@univ-orleans.fr
} 


\section{Introduction}

The proton exchange membrane fuel cell (PEMFC) offers attractive mass market applications. Its efficiency strongly depends on the membrane-electrodes assembly, and one of the challenges in its commercialization is the high cost of noble metals used as catalyst (e.g., Pt) in the electrodes. Increasing Pt utilization efficiency in order to decrease Pt amount in the catalytic layer has been one of the major concerns during the past decade [1-3]. In earlier work, we reported on the role of plasma sputtered deposited Pt on carbon electrodes as a technique for improving PEMFC efficiency [4-9]. It was demonstrated that plasma sputtering of catalyst is a suitable method for obtaining an efficient use of the catalyst. Moreover, $\mathrm{Pt} / \mathrm{C}$ nanostructures have recently been grown on silicon wafer and carbon-cloth using a combination of iron evaporation, microwave plasma enhanced CVD, and sputtering methods [10-13].

The next section is devoted to experimental devices involved in the studies. In the third section we will present and discuss the results of high performance electrodes with ultra-low Pt loading down to $0.01 \mathrm{mg} \mathrm{cm}^{-2}$. The last section will summarize and conclude the work.

\section{Experimental}

A plasma magnetron sputtering device is able to produce two electrodes of size $20 \mathrm{x} 20 \mathrm{~cm}^{2}$. The deposition chamber is equipped with two rectangular targets: one of pure carbon and one of $\mathrm{Pt}_{0.01}$ Carbon $_{0.99}$. Deposition conditions are the followings: power $530 \mathrm{~W}$, target voltage 700 $\mathrm{V}$, target current $0.78 \mathrm{~A}$. The growth rate is $4 \mathrm{~nm} \mathrm{~min}^{-1}$. The target to substrate distance is 6.5 $\mathrm{cm}$. Targets are $45^{\circ}$ tilted with respect to the substrate. Conventional uncatalyzed E-Tek ${ }^{\circledR}$ carbon porous layers on a carbon woven web are used as substrates. The Pt and C sputtered atoms are deposited to obtain $0.01 \mathrm{mg} \mathrm{cm}^{-2}$ Pt loaded electrodes. A second magnetron sputtering device is used for deposition of $0.16 \mathrm{mg} \mathrm{cm}^{-2} \mathrm{Pt}$ loaded $15 \times 15 \mathrm{~cm}^{2}$ electrodes from 
a 10 inches cylindrical pure Pt target. The Pt loadings and distributions into the porous layer are measured using Rutherford Backscattering Spectroscopy RBS. The as-built electrodes are observed using Scanning Electron Microscopy SEM (Hitachi S-4800). Membrane Electrode assemblies (MEAs) are prepared by simply tightening the membrane sandwiched between symmetric electrodes between two graphite bipolar plates at a $2 \mathrm{Nm}$ torque. No preliminary hot pressing process of electrodes against the Nafion ${ }^{\circledR} 212$ or 115 membranes (used as received from Electrochem. Inc.) was performed. No Nafion ${ }^{\circledR}$ solution is added in the electrode catalytic layers before use. $5 \mathrm{~cm}^{2}$ PEMFC tests using pure $\mathrm{H}_{2}$ and $\mathrm{O}_{2}$ gases are performed using ECL150/MTS 150/HSA units (Electrochem Inc.).

\section{Results and discussion}

Fig. 1 displays the SEM picture of a selected representative area of the $0.01 \mathrm{mg} \mathrm{cm}^{-2} \mathrm{Pt}$ loaded electrodes. Platinum is growing on the carbon particles as clusters. The Pt mean cluster size is less than $2 \mathrm{~nm}$. During deposition, Pt atoms also diffuse in the porous layer [5, 14]. The resulting platinum depth profiles were measured using RBS [15]. Fig. 2 shows the Pt depth profile extending down to $500 \mathrm{~nm}$ for a Pt load of $0.01 \mathrm{mg} \mathrm{cm}{ }^{-2}$. This penetration depth is rather important and is due to the deposition method, which allows depositing atoms with high kinetic energy $[4,16]$. A four-step process occurs during deposition: transport in the porous layer pores, adsorption on carbon particle surface, platinum diffusion on the carbon particles and Pt cluster growth.

Fig. 3 and 4 give the resulting voltage/power density vs current density curves obtained using MEAs made from Nafion ${ }^{\circledR} 212$ and Nafion ${ }^{\circledR} 115$ sandwiched between both Pt sputtered

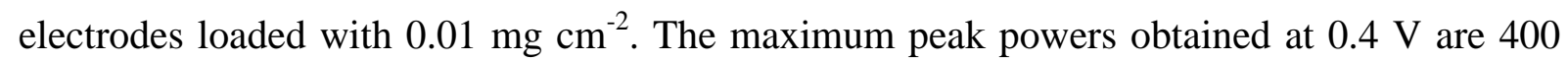
$\mathrm{mW} \mathrm{cm}{ }^{-2}$ and $170 \mathrm{~mW} \mathrm{~cm}{ }^{-2}$ for MEAs with Nafion ${ }^{\circledR} 212$ and Nafion ${ }^{\circledR} 115$, respectively. The performance using Nafion ${ }^{\circledR} 115$ is half the performance using Nafion ${ }^{\circledR} 212$, as expected. The

maximum reached current density is also reduced when using Nafion $^{\circledR} 115$. As a comparison, 
Fig. 5 displays the voltage/power density vs current density for a $0.16 \mathrm{mg} \mathrm{cm}^{-2}$ low Pt loaded electrodes. The maximum power density, $700 \mathrm{~mW} \mathrm{~cm}^{-2}$, is reached at $0.5 \mathrm{~V}$. This value is consistent with previously reported ones with conventional electrodes [17], but with 3.5 times less platinum.

Such a level of efficiency leads to mass specific power for the different MEAs of 20, 8.5 and

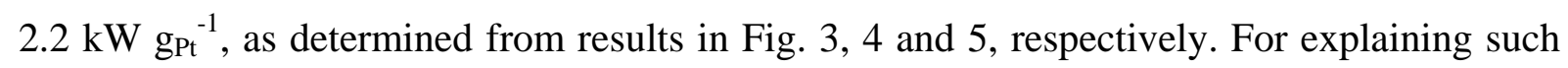
results, especially the one at $0.01 \mathrm{mg} \mathrm{cm}^{-2} \mathrm{Pt}$ loading, obtained without any standard preparation of the MEAs, we should mention that particle size (close to $2 \mathrm{~nm}$ ), deposition structure (co-deposition of Pt and C) and platinum repartition (localisation of platinum close to the membrane electrolyte surface) in the electrodes prepared here allows realizing with high efficiency the fuel cell electrochemical reactions at both electrodes. This is a particularly good result especially at the cathode, where kinetics of oxygen reduction reaction is known to be very low. Our results are in contrast with previous ones where only anode Pt mass was

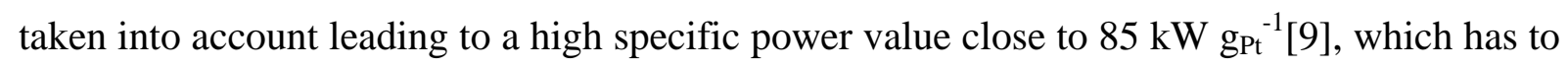
be reduced to $1.7 \mathrm{~kW} \mathrm{~g} \mathrm{gt}^{-1}$ when taking into account the Pt cathode mass. Previous successful attempts were concerned with the use of carbon nanotubes [8] or nanofibers [18], keeping a

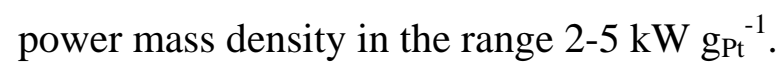

We should also recall that the plasma sputtering method allows to control the particle size and also to create "sticking" defects [19-22], which may have some importance in the electrocatalytic activity. Moreover, the deposition is not performed with platinum alone but consists in platinum carbon co-sputtering. The performance reached under these conditions seems to be higher than that achieved with deposition of Pt alone. This would indicate that codepositing carbon favours both the efficiency and the utilization of platinum. At last, the low penetration depth of platinum in the electrode does not require the needs for brushing the plasma catalyzed electrodes with Nafion ${ }^{\circledR}$ solution as usual. This is due to the fact that 
platinum clusters remains closed to the Nafion ${ }^{\circledR}$ membrane during fuel cell operation. When operating the fuel cell, the membrane is humidified; it then swells itself and, allowing to realize the triple phase boundary for practically all platinum particles.

\section{Conclusions}

Ultra-low Pt content PEMFC electrodes $\left(10 \mu \mathrm{g} \mathrm{cm}^{-2}\right)$ have been manufactured using magnetron co-sputtering of carbon and platinum on a commercial E-Tek uncatalyzed gas diffusion layer. Particle size, deposition structure and platinum repartition leads to high electrodes efficiency for both hydrogen oxidation and oxygen reduction reactions. PEMFC performance achieved with such low platinum loaded electrodes (anode and cathode) of 400 $\mathrm{mW} \mathrm{cm}{ }^{-2}$ corresponding to a specific power of $20 \mathrm{~kW} \mathrm{~g}_{\mathrm{Pt}}^{-1}$ is to our knowledge the highest presented in the literature at present. This technology also allows avoiding the use of Nafion ${ }^{\circledR}$ in the electrode and is easily transferable to industrial process.

\section{Acknowledgements}

Financial support from Communauté d’Agglomération du Drouais (CAdD), European Union (ESF), Ministère de la Recherche, Conseil Régional du Centre, Conseil Général Eure et Loir are gratefully acknowledged. 


\section{References}

1. B. C. H. Steele, A. Heinzel, Nature 414 (2001) 345.

2.R. O’Hayre, , S.-J. Lee, S.-W. Cha and F.. B. Prinz, J. Power Sources 109 (2002) 483.

3. S. Hirano, J. Kim and S. Srinivasan, Electrochim. Acta 42 (1997) 1587.

4. P. Brault, A. Caillard, A.-L. Thomann, J. Mathias, C. Charles, R. W. Boswell, S. Escribano, J. Durand, T. Sauvage, J. Phys. D 37 (2004) 3419.

5. A. Caillard, P. Brault, J. Mathias, C. Charles, R. W. Boswell, Surf. Coat. Technol. 200 (2005) 391.

6. P. Brault, S. Roualdès, A. Caillard, A.-L. Thomann, J. Mathias, J. Durand, C. Coutanceau, J.-M. Léger, C. Charles, and R. Boswell, Eur. Phys. J. Appl. Phys. 34 (2006) 151.

7. A. Caillard, C. Charles, R. Boswell , P. Brault, C. Coutanceau, Appl. Phys. Lett. 90 (2007) 223119.

8. A. Caillard, C. Charles, R. Boswell, P. Brault, Nanotechnology 18 (2007) 305603.

9. A. Caillard, C. Charles, D. Ramdutt, R. Boswell, P. Brault, J. Phys. D 42 (2009) 045207.

10. C.-L. Sun, L.-C. Chen, M.-C. Su, L.-S. Hong, O. Chyan, C.-Y. Hsu, K.-H., Chen, T.-F. Chang, L. Chang, Chem. Mater. 17 (2005) 3749.

11. C.-C. Chen, C. F. Chen, C.-H. Hsu, and I.-H. Li, Diamond Relat. Mater. 14 (2005) 770.

12. H. Rabat, P. Brault, Fuel Cells 8 (2008) 81.

13. H. Rabat, C. Andreazza, P. Brault, A. Caillard, F. Béguin, C. Charles, R. Boswell, Carbon 47 (2009) 209.

14. P. Andreazza, C. Andreazza-Vignolle, J. P. Rozenbaum, A.-L. Thomann, P. Brault, Surf. Coat. Technol. 151-152 (2002) 122.

15. M. Mayer, “A simulation program for the analysis of NRA, RBS and ERDA”, in technical reports IPP9/113, Max-Planck-Institut für PlasmaPhysik, Garching, 1997.

16. A. Gras-Marti, J. A. Valles-Abarca, J. Appl. Phys. 54 (1983) 1071. 
17. S. Litster, G. McLean, J. Power Sources 130 (2004) 61.

18. H.-T. Kim, J.-K. Lee, J. Kim, J. Power Sources 180 (2008) 191.

19. A.-L. Thomann, P. Brault, J. P. Rozenbaum, C. Andreazza-Vignolle, P. Andreazza, H. Estrade-Szwarckopf, B. Rousseau, D. Babonneau, G. Blondiaux. J Phys D: Appl Phys 30 (1997) 3197.

20. A.-L. Thomann, C. Charles, P. Brault, C. Laure, R. Boswell, Plasma Sources Sci Technol. 7 (1998) 245.

21. P. Brault, A. L. Thomann, C. Andreazza-Vignolle, Surf. Sci. 406 (1998) L597.

22. A.-L. Thomann, J. P. Rozenbaum, P. Brault, C. Andreazza-Vignolle, P. Andreazza, Appl. Surf. Sci. 158 (2000) 172 
Figure caption:

Fig. 1: Scanning electron microscopy picture of a $0.01 \mathrm{mg} \mathrm{cm}^{-2} \mathrm{Pt}$ loaded electrodes. White dots are platinum clusters (courtesy of D. Cot, IEM).

Fig. 2: Platinum depth profile into the porous layer as determined from RBS measurements.

Fig. 3: $E(j)$ and $P(j)$ curves obtained with a MEA made of ultra-low loaded electrodes (0.01 mg cm${ }^{-2}$ ) mechanically pressed against a Nafion ${ }^{\circledR} 212$ membrane.

Flow rates: $\mathrm{O}_{2}=0.35 \mathrm{sccm}, \mathrm{H}_{2}=0.5 \mathrm{sccm} ; \mathrm{P}_{\mathrm{O}_{2}}=3.8$ bars, $\mathrm{P}_{\mathrm{H}_{2}}=3.1 \mathrm{bar}, \mathrm{T}_{\mathrm{O}_{2}}=40^{\circ} \mathrm{C}$, $\mathrm{T}_{\mathrm{H}_{2}}=80^{\circ} \mathrm{C} ; \mathrm{T}_{\text {cell }}=80^{\circ} \mathrm{C}$.

Fig. 4: Performance $E(j)$ and $P(j)$ curves obtained with a MEA made of ultra-low loaded electrodes (0.01 $\left.\mathrm{mg} \mathrm{cm}^{-2}\right)$ mechanically pressed against a Nafion ${ }^{\circledR} 115$. Same experimental conditions as in Fig. 3.

Fig. 5: Performance $E(j)$ and $P(j)$ curves obtained with a MEA made of ultra-low loaded electrodes (0.16 mg cm${ }^{-2}$ ) mechanically pressed against a Nafion ${ }^{\circledR} 212$. Same experimental conditions as in Fig. 3. 


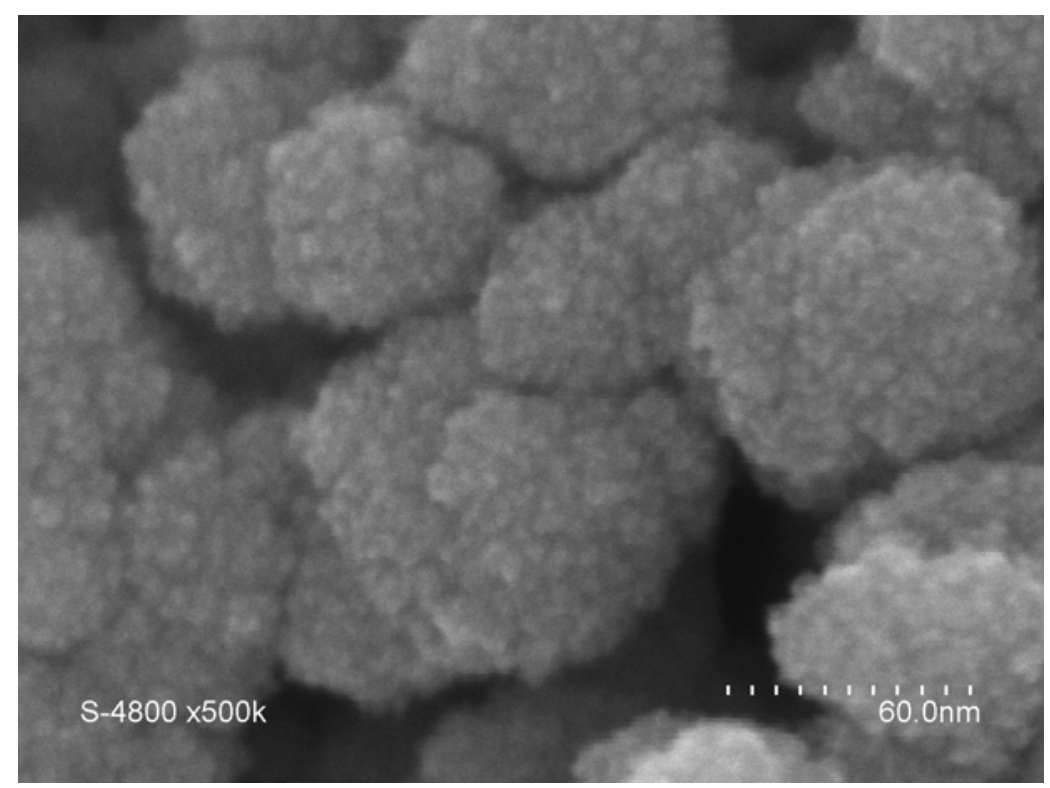

Fig. 1 


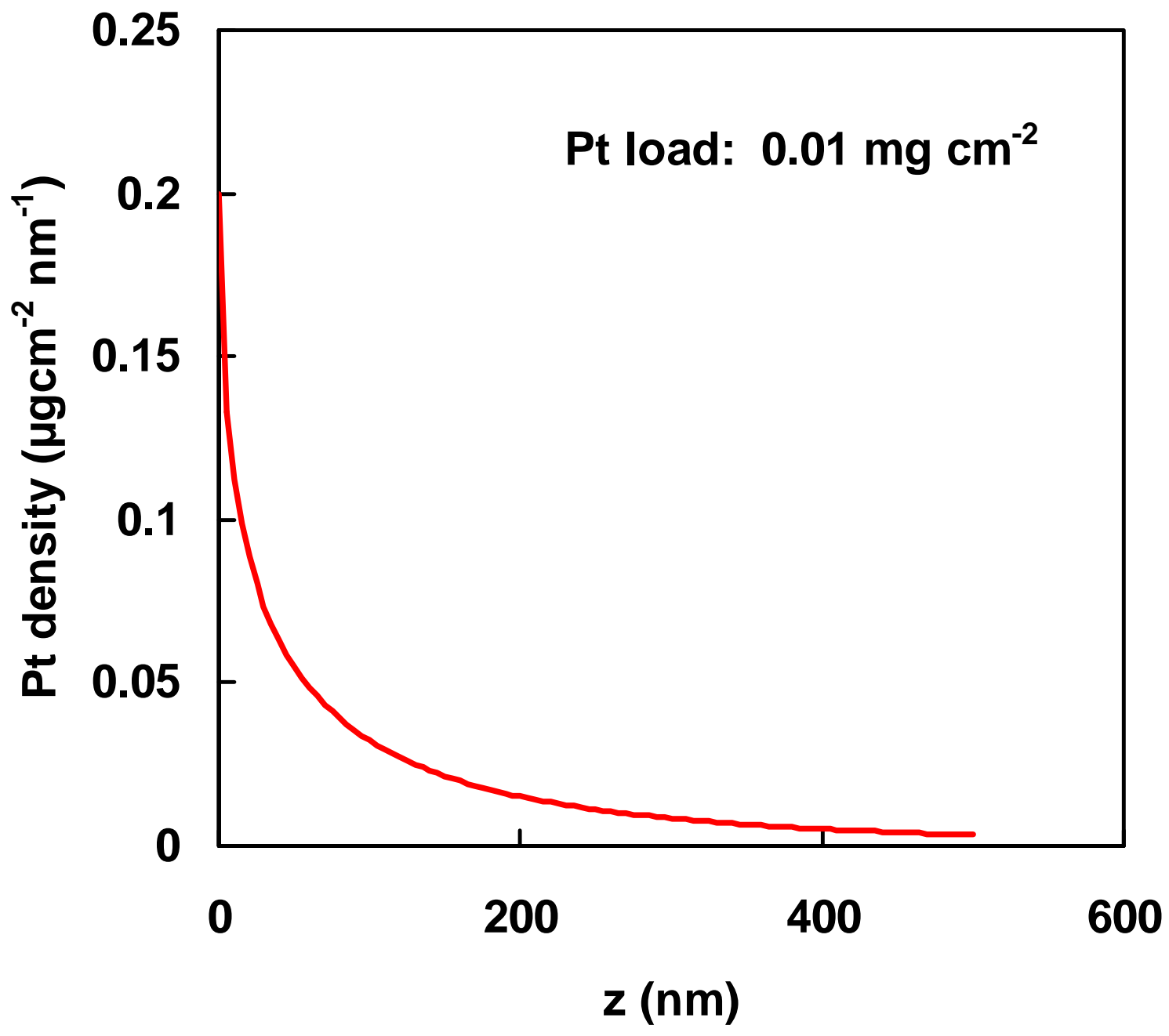

Fig. 2 


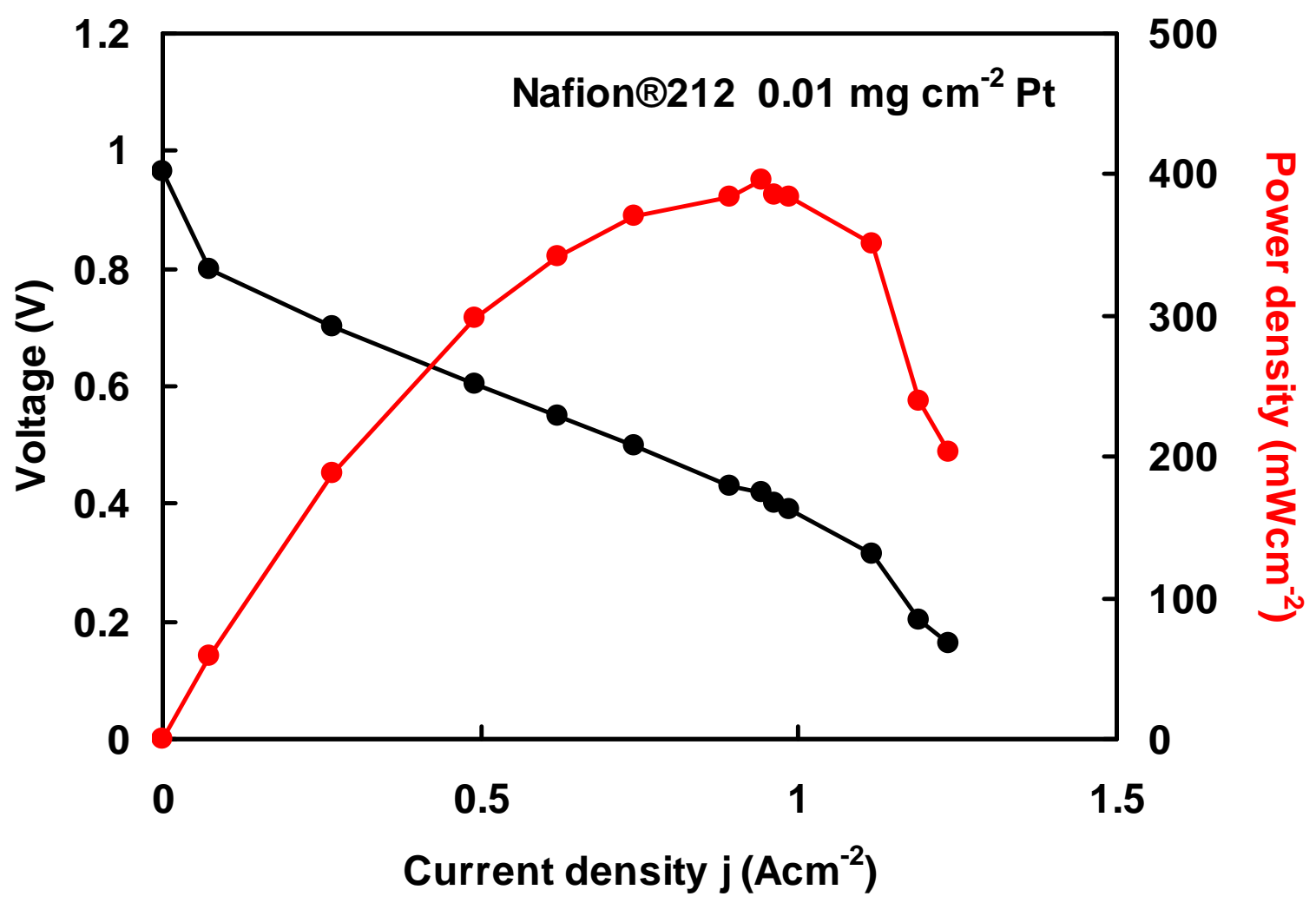

Fig. 3 


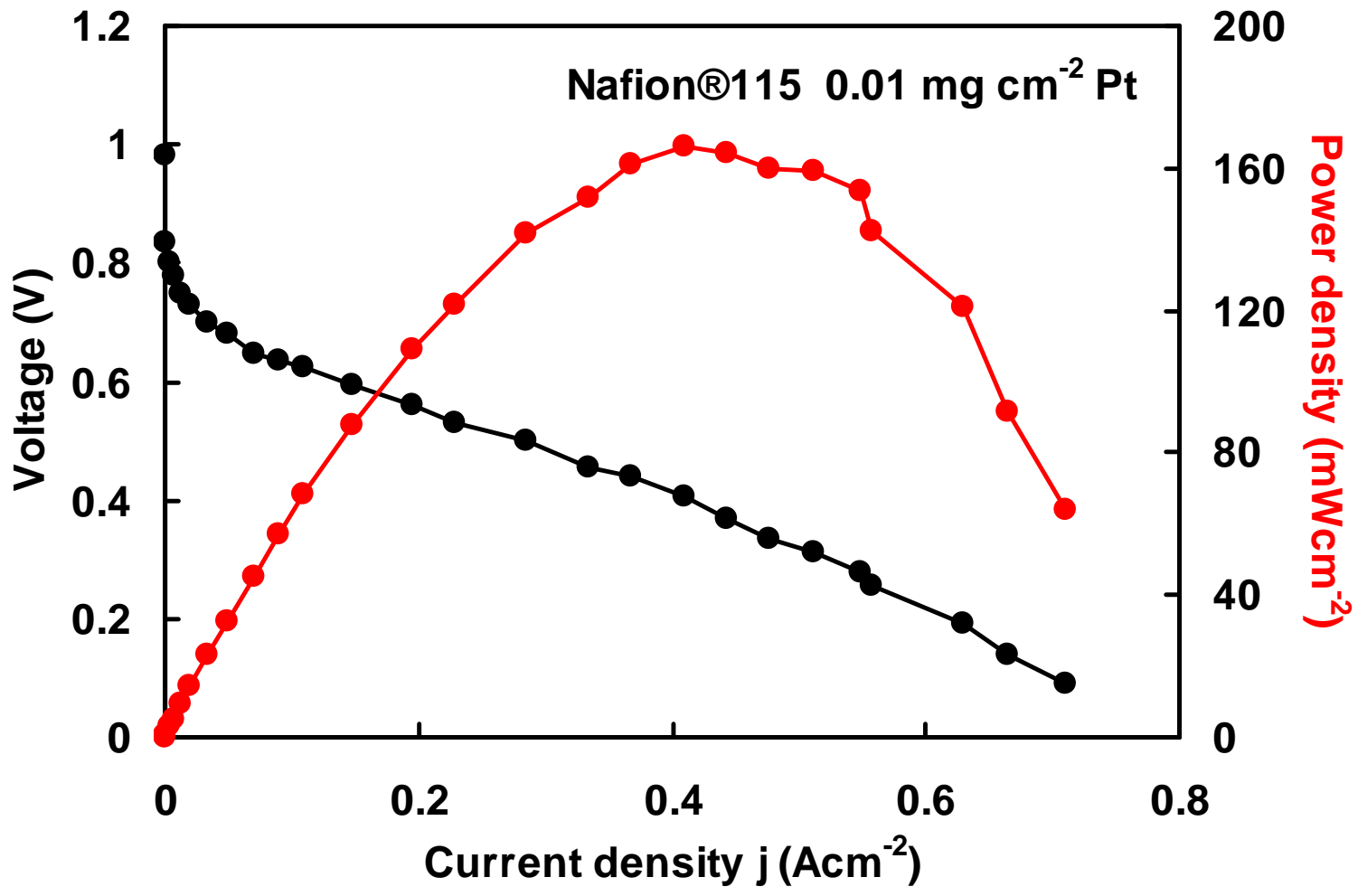

Fig. 4 


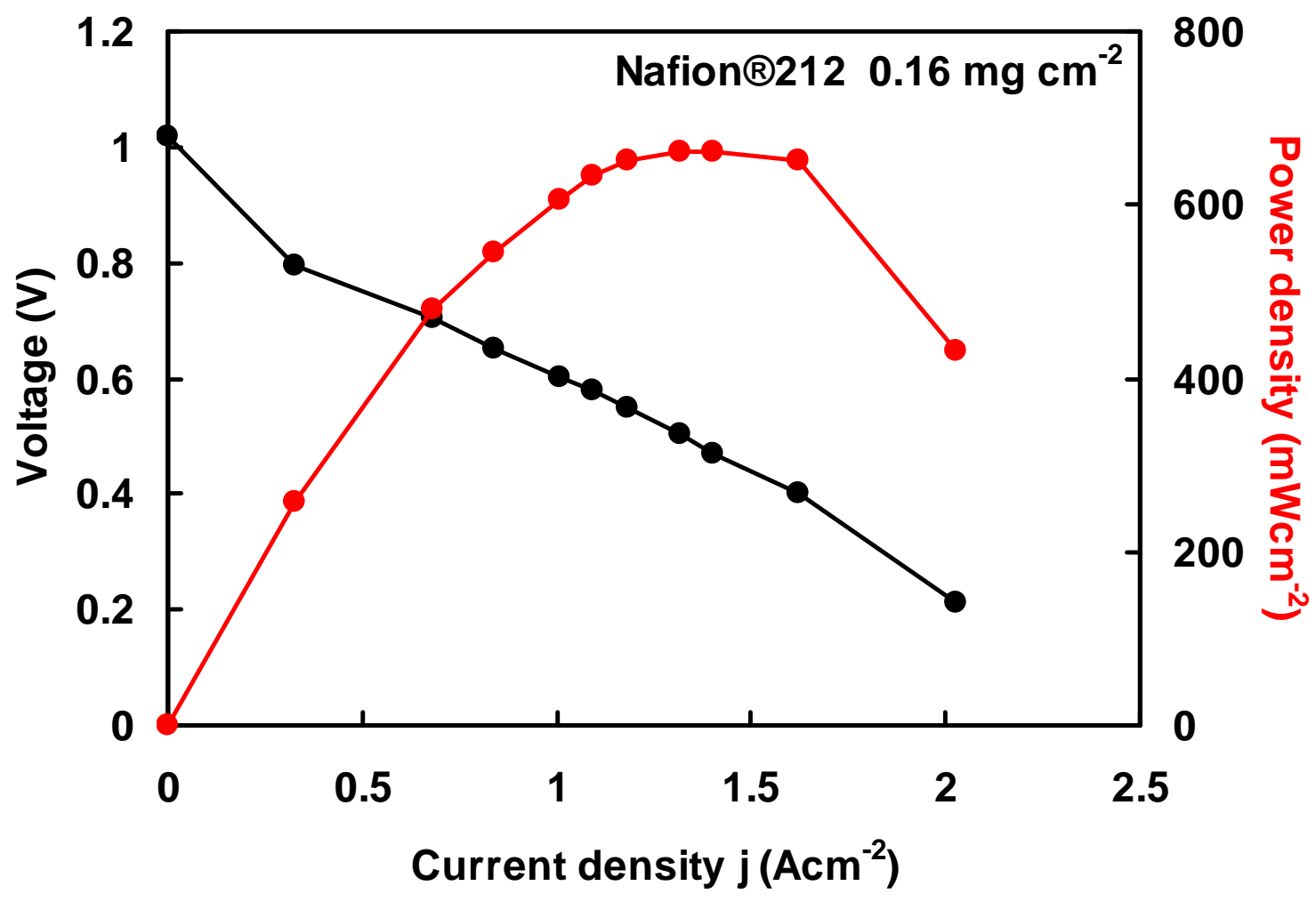

Fig. 5 